\title{
O design sonoro de material de arquivo na representação do horror trágico: uma análise de México (2002), de Alejandro González-Iñarritu
}

\author{
Tatiana Aneas \& Guilherme Maia*
}

Resumo: Este artigo busca investigar os modos de produção de sentido e afeto mobilizados pelo filme Mexico (2002), de Alejandro González Iñarritu. Para tanto, é feito um esforço de articulação entre dois autores da análise fílmica, a saber, Gomes (1996, 2004a, 2004b) e Odin $(2004,2011,2012)$ com o objetivo de estabelecer um ponto de vista teórico-metodológico para a análise pretendida. Partimos da hipótese de que o filme se propõe a ser interpretado e experimentado como um documento, e que esta estratégia é fundamental para pôr em operação o programa poético desta obra, no qual o design do material de arquivo sonoro tem papel decisivo.

Palavras-chave: análise fílmica; design de som; Poética; modos de leitura.

Resumen: En este trabajo se investiga los modos de producción de sentido y afecto movilizados por la película México (2002), de Alejandro González Iñárritu. Para ello, se hace un esfuerzo de articulación entre dos autores del análisis fílmico, a saber, Gomes (1996, 2004a, 2004b ) y Odin (2004, 2011, 2012), con el fin de establecer un punto de vista teórico-metodológico para el análisis pretendido. Partimos de la hipótesis de que la película propone ser interpretado y experimentado como un documento, y que esta estrategia es fundamental para poner en funcionamiento el programa poético de esta obra, en la que el diseño de material de archivo sonoro tiene un papel decisivo. Palabras clave: análisis fílmico; diseño de sonido; poética; modos de lectura.

\begin{abstract}
This paper investigates the meaning production and affection processes mobilized by Mexico film (2002), by Alejandro González Iñarritu. Therefore, it is constructed a joint effort between two authors of film analysis, namely, Gomes (1996, 2004a, 2004b) and Odin $(2004,2011,2012)$ in order to establish a theoretical and methodological point of view to analysis. Our hypothesis is that the film intended to be interpreted and experienced as a document, and that this strategy is essential to put into operation the poetic program of this film, in which the sound archive material design plays a decisive role.
\end{abstract}

Keywords: film analysis; sound design; poetic; reading modes.

Résumé: Cet article examine les processus de production de sens et d'affect mobilisés par le film Mexico (Alejandro González Iñarritu, Angleterre, 2002). Pour ce faire, on

* Tatiana Aneas: Doutoranda. Universidade Federal da Bahia, Faculdade de Comunicação, Programa de Pós-Graduação em Comunicação e Cultura Contemporâneas. 40110-060, Salvador, Brasil. E-mail: tatiana.aneas@ gmail.com

Guilherme Maia: Universidade Federal da Bahia, Faculdade de Comunicação, Programa de Pós-graduação em Comunicação e Cultura Contemporâneas. 40110-060, Salvador, Brasil. E-mail: maia.au diovisual@gmail.com

Submissão do artigo: 08 de janeiro de 2016. Notificação de aceitação: 09 de fevereiro de 2016. 
s'est efforcé d'articuler deux auteurs de l'analyse filmique - Gomes (1996, 2004a, 2004b) et Odin $(2004,2011,2012)$ - avec pour objectif d'établir un point de vue théorique et méthodologique pour l'analyse souhaitée. Nous partons de l'hypothèse que le film se propose d'être interprété et expérimenté comme un document, et que cette stratégie est essentielle pour faire fonctionner le programme poétique de cette œuvre, dans laquelle le design du matériau d'archive sonore joue un rôle décisif. Mots-clés: analyse filmique; design sonore; poétique; modes de lecture.

Muitos são os modos possíveis de analisar um produto audiovisual. Em geral, a escolha por um método de abordagem, por um modo de investigar, depende das perguntas às quais o filme nos convoca - como espectadores $\mathrm{e}$ como analistas. Considerar aspectos estéticos, econômicos, políticos, suas relações, ou estreitar o olhar para uma das dimensões de uma obra, são decisões que devem ser guiadas pela questão que se deve responder e pelas prováveis respostas a ela.

No caso de Mexico (Inglaterra/França, 2012, 11 min.), dirigido por Alejandro Gonzalez-Iñárritu, nos chama a atenção, em primeiro plano, as estratégias fílmicas que modelam nossas reações emocionais. Como somos colocados diante de representações que nos convocam ao horror, à comoção. Para o espectador, é construído um lugar de testemunha, e o filme se propõe a ser interpretado e experimentado como um documento (Odin, 2012). Nossa hipótese é que esta estratégia é fundamental para pôr em operação o programa poético desta obra (Gomes, 2004a, 2004b), e que, sem desconsiderar a importância do valor semântico das imagens, é na instância do projeto de som que esse programa poético manifesta com mais evidência suas estratégias e seu raro sabor. A análise que se segue tem o propósito de demonstrar a validade desta ideia.

Por se tratar de um problema que lida sobretudo com a dimensão estética do filme, com seus modos de produção de sentido, com os efeitos convocados, com as formas de leitura propostas pela obra, é que elegemos métodos dedicados à análise destes aspectos. Além da investigação do objeto propriamente, este artigo esboça uma possibilidade de articulação das premissas presentes em Odin (2012) e Gomes (2004a, 2004b). Isso porque nos interessa sobretudo o programa poético do curta, suas estratégias e recursos, que parece estar relacionado a um determinado contrato com o espectador - que podemos chamar modo de leitura documentarizante. $\mathrm{O}$ fenômeno fílmico, aqui, é a experiência do filme, e a forma como ela é tecida através da narrativa audiovisual.

Para breve contextualização, a peça é parte de uma série de onze curtasmetragens que relembram os atentados ao World Trade Center em 11 de setembro de 2001. Cada curta está sob responsabilidade de um diretor diferente, de diferentes nacionalidades. Dentre as onze obras que compõem o conjunto, esta 
é a única que opta por privilegiar a construção de um olhar documental sobre os acontecimentos. Ao contrário do que ocorre com os outros dez curtas, neste caso a narrativa não propõe um fragmento ficcional que de alguma maneira remete o espectador aos fatos históricos. O apreciador, antes, é confrontado com os registros, documentos sonoros e imagéticos, das cenas do horror real vivenciado pelos envolvidos nos atentados.

A partir disto, é possível imaginar que parte significativa do programa poético (Gomes, 2004a) desta obra esteja calcado em estratégias de composição que propõem para o apreciador um determinado contrato de leitura, no qual a premissa fundamental é a que ele está diante de uma representação que se promete um recorte do "real". Mais do que isso, o filme parece querer posicionar o espectador como uma testemunha daqueles acontecimentos.

No mesmo sentido, partindo do que Odin chama de "modo de produção de sentido documentarizante"(2012), é possível pensar que trata-se de uma obra que leva o espectador a pressupor um enunciador real como origem deste discurso que é a base da sua experiência fílmica. Isso porque o espectador é convidado a experimentar os acontecimentos tais como eles foram supostamente testemunhados e vividos por pessoas que estivessem no lugar e na hora em que ocorreram. Vale ressaltar que este não é o único modo de leitura mobilizado pelo filme. Há certamente um interesse por parte da obra de ser recebida também como objeto estético, por exemplo, que utiliza estratégias e recursos narrativos e audiovisuais pouco usuais, inovadores, criativos. São dimensões que não se excluem, trata-se, aqui, mais de uma questão de predominância. Até porque os efeitos produzidos (ou, pelo menos, a intensidade com que são produzidos) na apreciação são em certa medida derivados do fato de que tomamos aqueles sons e imagens como reais.

\section{Pressupostos teórico-metodológicos}

A análise aqui proposta está centrada nas estratégias de composição fílmica e os modos que a obra convoca e mobiliza o espectador. Por isso, o ponto de vista metodológico que irá ser construído é de natureza sobretudo textual, imanente. Em seguida apresentaremos premissas e desdobramentos metodológicos para esta análise derivados de Odin e Gomes.

De Odin e sua abordagem semiopragmática utilizaremos sobretudo a ideia de que determinados filmes, sob certas circunstâncias, podem desencadear diferentes "modalidades da produção de sentido e afetos"(Odin, 2011). Para o autor, estes modos são operadores de análise que objetivam dar conta dos processos de produção de sentido permitidos pelo filme. São operadores que intentam sobretudo revelar qual a recepção construída pelo texto, a partir do tipo 
de experiência comunicacional que provocam e das operações de interpretação que mobilizam. E que podem variar dependendo do público e da circunstância de recepção, mas cujas possibilidades estarão sempre previstas na composição do filme de alguma maneira - ou, ao menos um conjunto restrito de possibilidades de interpretação. Todo filme programa, de alguma forma, os modos pelos quais pode ser interpretado.

Abstrair a modalidade que predomina neste processo significa compreender "os tipos de espaço permitidos pelo texto, as formas de colocação discursiva aceitas, as relações afetivas possíveis de serem instauradas pelo filme, e a estrutura enunciativa que o produto autoriza o receptor a produzir"(Odin, 2004: 33). A depender dos processos desencadeados, então, Odin defende que o modo de leitura pode ser ficcionalizante, documentarizante, espetacularizante, artístico, estético, energético ou privado (idem: 36).

Por leitura documentarizante entendemos toda "leitura capaz de tratar o filme como documento"(Odin, 2012: 13), o que parece estar exemplificado em Mexico. Para o espectador, a origem do discurso fílmico é um enunciador real - ou melhor, o espectador pressupõe a realidade do enunciador. "Nessa perspectiva, tudo o que se encontra diante da câmera (cenários, figurinos, personagens etc.) torna-se objeto da leitura documentarizante."(idem: 17). Em Mexico, as imagens e sons apresentados devem ser tomados como fragmentos de uma realidade caótica e horrível. A câmera, e o apreciador, são construídos como verdadeiras testemunhas oculares, e o filme ganha sentido por ser um registro, por captar o que acontece ali naquele momento, estabelecendo relação quase indexical entre as imagens e o que elas representam.

Ao tratar dos recursos estilísticos comuns aos filmes de reportagem, percebemos que muitos deles estão presentes em Mexico, embora esta classificação não pareça ser suficiente para explicar esta obra.

No nível da imagem: flou [foco embaçado], tremulação da imagem, travellings aos solavancos, panorâmicas hesitantes, golpes de zoom, rupturas brutais no desenvolvimento dos planos e no encadeamento das sequências, longos planos-sequências, iluminação deficiente, grão da película (...) No nível do som: timbre específico do som direto (por oposição ao som de estúdio: ausência de ressonância), ruído, estrutura linguística da palavra "viva"(...). (Odin, 2012: 25).

É preciso, porém, ressalvar que a perspectiva de Odin não propõe uma leitura estritamente imanente. Embora o artigo de Odin intitulado: "Filme documentário, leitura documentarizante", e publicado no Brasil em 2012, sobre o filme documentário apresente uma tendência mais centrada no filme em si, é igualmente verdade que sua pesquisa (Odin, 2004, 2011) tende a propor uma terceira via entre perspectivas imanentistas e contextualistas. É por isso que o 
autor defende a importância de se considerar os espaços de produção, e sobretudo os espaços de recepção em que o filme é percebido. Isso porque, além das restrições internas à obra (como os créditos inicias que impõem uma leitura fictivizante ao informar que existe a interpretação de atores), existe também um feixe de restrições relativos ao contexto em que estas obras são recebidas (Odin, 2004: 21). Daí que um mesmo filme de ficção pode ser interpretado a partir de um olhar estético quando apreciado em festivais, por exemplo, ou a partir de um modo de produção de sentido documentarizante quando recebido no contexto de um curso de cinema.

Nesta investigação especificamente, a compreensão deste contexto de produção ou recepção não está no centro da problemática que se pretende dar conta. Por isso, este aspecto do pensamento do autor não é discutido no sentido de transformá-lo em operador de análise. O que, por outro lado, não significa dizer que não seja possível fazê-lo, inclusive com resultados significativos.

É no ponto em que defende a existência de elementos internos ao filme que modelizam sua interpretação que a semiopragmática de Odin encontra a poética do filme de Gomes. É também em Gomes que encontraremos indicações de procedimentos metodológicos adotados nesta análise.

A partir de leituras de Aristóteles, Eco e Pareyson, Gomes afirma que, tal como Aristóteles, está interessado em objetos cuja representação está baseada na mímeses (imitação), isto é, na representação de ações por personagens - o que a teoria contemporânea do audiovisual chama narrativas. Gomes vai se inspirar na Poética para pressupor que uma obra pode ser pensada a partir da sua destinação, o seu propósito, sua finalidade. E, para Aristóteles, a destinação de uma obra é o seu efeito. Ou melhor, é produzir o efeito para o qual ela foi composta, programada. Assim, uma tragédia bem-sucedida não deve fazer outra coisa que provocar horror e compaixão, assim como a comédia deve produzir graça, necessariamente. Tratam-se de efeitos emocionais que dizem respeito aos gêneros aos quais estas obras se filiam.

Ele chama a atenção para o fato de que os efeitos somente podem se efetivar na apreciação, com a participação de um receptor ou apreciador. Mas que, por outro lado, este efeito é previsto na criação e as suas instruções de ativação estão presentes na obra, através da sua composição. Trata-se de um conjunto de premissas para uma perspectiva analítica que se ocupe em investigar "os efeitos da composição e da relação entre tais efeitos realizados e as estratégias presentes em tal composição" (Gomes, 2004a: 21). Ou seja, ao partir para a análise de um filme, uma chave analítica viável seria questionar sobre os efeitos que ele produz e como ele os produz - através de quais estratégias e recursos. "A poética estaria, então, voltada para identificar e tematizar os 
artifícios que no filme solicitam esta ou aquela reação, esse ou aquele efeito no ânimo do espectador"(Gomes, 2004a: 23).

Uma segunda orientação metodológica da Poética indica que, se queremos observar efeitos e estratégias, o objeto de tal análise deve ser a experiência fílmica. Isso porque é somente através dela que é possível observar os efeitos; é na textura do filme que estão inscritas essas estratégias, e não no discurso do realizador ou da crítica.

O procedimento metodológico então prescreve que se identifique, primeiro, a natureza dos efeitos produzidos ou do lugar construído pelo filme para o apreciador. Alguém poderia dizer que a apreciação empírica comporta nuances e diferenças entre os efeitos produzidos, a depender de múltiplos fatores - como seja o contexto de recepção. Mas, neste caso, trata-se de identificar os efeitos permitidos pelo filme, previstos pelo texto, e nada além disto. Por fim, Gomes vai propor que a peça fílmica seja decomposta em três estágios de organização dos seus elementos: efeitos, estratégias e meios ou recursos. E que o filme, enquanto máquina de produção de encantos, opera no sentido de produzir três tipos de efeitos no apreciador: cognitivos, sensoriais ou emocionais.

Este filme parece exemplar para operar a articulação entre os dois autores, uma vez que compreender a maneira como a obra posiciona seu espectador como testemunha, levando-o a construir um "enunciador pressuposto real"é fundamental para disparar na apreciação o programa poético previsto na obra. Esse movimento nos parece acertado sobretudo para defender que convocar um modo de leitura documentarizante é parte substancial das estratégias de produção de efeitos que compõem Mexico, e que fazem deste filme uma obra singular.

\section{Analisando Mexico}

Cabe agora examinar mais atentamente as principais estratégias e recursos compositivos que concorrem para posicionar o espectador desta maneira específica e para nele fazer operar seu programa de efeitos. Programa este que, no aspecto emocional, está baseado sobretudo na produção de horror e compaixão. ${ }^{1}$ Sentimentos descritos por Aristóteles como derivados de uma experiência em que presenciamos um outro, semelhante a nós, em situação de infortúnio. Interessante notar que, para o clássico, tratam-se dos efeitos típicos da tragédia. E Iñárritu parece fazer questão de apresentar o ataque às torres gê-

1. Discussão presente n’Arte Poética de Aristóteles (2006). 
meas como um acontecimento trágico - aqui não causado pelo acaso ou pelo destino, mas pela incapacidade do homem de lidar com a diferença.

Vale ainda observar que, embora aproxime o espectador desta "realidade" experimentada, o filme não o faz com o intuito de objetivar essa relação com os atentados. Ao contrário, há claramente uma estratégia de nos fazer comover com as reações tão "verídicas" e espontâneas que vemos e ouvimos sobretudo ouvimos. Parece que, ao mobilizar um modo de leitura documentarizante, ao nos fazer crer que tudo aquilo aconteceu de fato e daquela maneira, o filme intensifica seus efeitos emocionais. Afinal, não são com personagens fictícios que estamos nos identificando, mas com pessoas de carne e osso, que presenciaram, viveram (e morreram) aquela situação extrema. O modo como o material de arquivo é organizado pela montagem é decisivo nesse processo. Os sons e as imagens registrados no momento em que o fato ocorreu não estão no filme como mera prova ou espelhamento de algo acontecido, mas sim, como recomenda Didi-Huberman (2012), transformado em narrativa e matéria expressiva, por meio de recortes e de uma montagem cruzada que estabelece relações entre arquivos e também com outros materiais de expressão.

Em um regime minimalista severo na dimensão visual, o que o filme mais nos mostra é o nada, o vazio. Ao longo dos cerca de 11 minutos de duração, nós, os espectadores, olhamos para aproximadamente 8,5 minutos de tela preta. No pouco tempo restante, o que mais vemos são breves inserts de planos abertos, em baixa resolução, que "rasgam" a tela preta para nos mostrar quadros compostos por partes do céu, a fachada de um edifício e algumas poucas figuras humanas vistas à distância. Em um filme de natureza tão rara, as estratégias sonoras se impõem naturalmente como foco de qualquer análise. Optamos aqui por observar, especialmente, o modo como o material de arquivo, associado ao design de som, é organizado como estratégia de afetação cognitiva, sensorial e emocional, atentos ao fato de que quem assina a arte sonora do filme é o próprio diretor, em parceria com o cantautor Gustavo Santaolalla.

O espetáculo começa com silêncio e uma tela preta que se estende por cerca de dois minutos e vinte segundos. O primeiro evento da trilha sonora é o que, em música, chamamos de um crescendo dal niente, ou seja, um fade in a partir do silêncio, de vozes entoando Salás, o "canto falado" com textos do Alcorão dos rituais muçulmanos de reza. O crescendo, em passo lento, é acompanhado por um aumento progressivo no grau de densidade das vozes: um número cada vez maior de pessoas entoa rezas com textos e "afinações" diferentes, não sincronizadas ritmicamente. Ouvidas, a princípio, como se proferidas à distância, as vozes que oram chegam, pouco a pouco, cada vez mais perto de nós. Pressupondo que o leitor-modelo (Eco, 1994) da obra não entende o idioma, o 
canto falado coletivo assincrônico molda um mantra heterofônico e microtonal, decerto não desprovido de grande beleza plástica. Entretanto, o constante crescendo e as tensões harmônicas, associados à ausência de outra informação na tela que não a cor preta, produzem também um crescente sentido de inquietação, processo do qual, é claro, participa o registro que temos na memória do conflito entre determinados grupos islâmicos e os EUA massivamente difundido pelos meios de comunicação. Ademais, o espectador previsto na obra bem sabe que está assistindo a uma série de filmes curtos sobre o ataque às Torres Gêmeas.

Seguem as vozes e ouvimos um primeiro "baque" surdo - um impacto - em volume moderado. Um segundo som de impacto, com mais volume e presença, é seguido de outros, espaçadamente e em variada dinâmica. Neste ponto, o som de impacto é matéria sonora quase "pura", que afeta a escuta reduzida - a qualidade do som em si - e põe em movimento a causal - a busca de uma relação do signo sonoro com algum referente (Chion, 2011): que som é esse, que surge no meio das vozes desses homens muçulmanos que rezam e chegam cada vez mais perto de nós? O primeiro movimento da cognição, na ausência de outro input, sobretudo na ausência de imagens, é o de buscar atribuir um sentido mínimo ao que é dado à percepção. Mesmo as primeiras imagens, no entanto, apresentadas em planos que duram frações de segundo, não dão conta de explicitar a fonte deste som que, a princípio, só não passa despercebido em meio à heterofonia das rezas porque é reiterado e, assim, se impõe como signo em busca de um significado.

Seguem os sons de impactos espaçados, somados às vozes. Em fluxo dinâmico também dal niente, emerge aquilo que no jargão do design de som chamamos de drone, um som contínuo na região médio-grave (no caso em análise, uma nota musical sustentada), recurso via de regra utilizado para produzir a sensação de tensão, muitas vezes como um sinal de que algo grave está para acontecer. Com a mesma dinâmica em crescendo, a região médio-aguda vai sendo preenchida pelo som de um trinado em instrumento metálico da família dos idiofones de agitação (como os guizos). Percebe-se, portanto, uma estratégia de superposição de camadas sonoras, que opera pelo menos em três níveis: na dimensão cognitiva, reconhecemos a presença do Islã no filme, enquanto saboreamos um efeito de natureza sensorial de beleza, mas também de crescente tensão, uma vez que rezas, impactos e drone são oferecidos à escuta em dinâmica cada vez mais forte, excitando nossas expectativas em frente à tela "muda".

Um som de impacto em dinâmica mais forte que todos os anteriores dá acento sonoro à primeira e brevíssima imagem que o filme oferece: durante 
um terço de segundo, vemos uma seção da fachada de um prédio, o céu e o que parece ser algo em queda livre. A seguir, a tessitura das notas sustentadas é progressivamente expandida, a princípio na região aguda, a seguir nos graves, enquanto continuamos a ouvir uma cortina densa composta pelo agitar dos "guizos". O resultado até aqui é uma massa heterofônica áspera que se torna a cada momento mais intensa, densa e tensa, operando, primordialmente, em um regime sensorial.

Um segundo ponto de sincronização (Chion, 2011) entre um som de impacto em volume mais alto e um drop de imagem semelhante ao anterior (2/3 de segundo), antecede o início do segundo ato da trilha sonora. Este é marcado pela mudança para um regime factual, com a entrada de uma voz masculina, que identificamos como emitida por uma estação de rádio ou TV anunciando, em inglês, as condições atmosféricas de "um esplêndido dia de setembro". Frase que a edição oferece à escuta com a entrada, em pano-de-fundo, de uma sutil melodia em tom menor, sem acompanhamento e executada no piano. É um esplêndido dia de setembro, mas uma melodia ao longe nos fala um pouco de tristeza. A frase do locutor é repetida em loop enquanto ouvimos, em fade in, o som de um avião a jato em voo, que vai do pianíssimo ao fortíssimo.

É sobre um fundo intensamente cacofônico, formado por uma massa densa de ruídos de colisão, sirenes, estática de comunicação por rádio, vozerio, motores e o trinado de "guizos" (que permanece constante até quase o final do filme), que escutamos agora o relato radiofônico de um repórter perplexo e desesperado dando conta dos acontecimentos que se desarrolam diante dos seus olhos. A ideia de que se trata de uma notícia via rádio é estabelecida pela vinheta da emissora antes da informação e pela "qualidade" do áudio. Uma impressão de que se trata de uma inserção ao vivo deriva do próprio conteúdo da fala do repórter, que não sabe descrever ao certo o que acontece diante dos seus olhos: ${ }^{2}$ o impacto dos aviões no World Trade Center. As vozes, que no primeiro ato tinham o tom das orações, agora são "gritos" de diversas vozes masculinas emocionadas que descrevem, em broadcast, o que está acontecendo. Tudo no material de arquivo e no design de som concorre para construir a percepção de que são testemunhos reais e para nos fazer imergir na atmosfera de perplexidade e caos do momento em que tudo aquilo aconteceu.

$\mathrm{O}$ ato sonoro seguinte, ainda sobre o mesmo fundo heterofônico denso e caótico, é a superposição de vozes masculinas de locutores, em vários idiomas, mostrando-nos a repercussão do fato no resto do mundo. A dinâmica e a densidade do drone são intensificadas. Um "crash" em alto volume, interrompe

2. "Estamos agora no World Trade Center, algo aconteceu aqui. Um avião, muita fumaça sai de uma das torres". 
subitamente o fluxo do drone na região grave, mas a sustentação do acorde tenso na região aguda permanece na trilha sonora. O "crash" coincide com o momento no qual um aumento no ritmo e na duração das imagens de arquivo deixa mais claro que o que está sendo mostrado são os jumpers. ${ }^{3}$ A mudança na textura da malha sonora marca o início de um novo parágrafo na narrativa, momento no qual um locutor, com voz emocionada, informa aos ouvintes de que há pessoas se jogando das janelas do prédio. O vazio na região grave faz com que ouçamos com mais clareza o som dos impactos que - agora temos certeza absoluta, mesmo em um regime assincrônico no qual jamais vemos corpos atingindo o solo -, trata-se do som da chegada ao chão dos corpos das pessoas que optaram por tentar sobreviver a um salto com muitas chances de ser mortal. Na progressão dramática, não são mais dois prédios que foram atingidos, são mulheres e homens desesperados. São, agora, "uns de nós".

Apesar de oferecidas à apreciação em doses mínimas, as imagens dos jumpers, mostradas em ritmo e duração crescentes, muitas vezes em conjunção com sons de impacto na trilha sonora, são decisivas no caráter da obra. Além de operarem na dimensão sensorial da progressão dramática (ritmo e duração crescentes), são decisivas no engajamento emocional do espectador, pois deixam claro que são imagens captadas no momento do acontecimento, o que é possível inferir a partir da qualidade destas capturas - imagens pouco nítidas, trêmulas, típicas de cinegrafistas amadores, embora não totalmente destituídas de certa beleza plástica - aquilo que Odin chamará de "instruções textuais"oriundas do sistema estilístico típico dos filmes de reportagem. Trata-se de mais uma estratégia para "pôr em ação o modo de leitura documentarizante"(Odin, 2012: 19).

3. Como ficaram conhecidos na imprensa norte-americana aqueles que foram obrigados a pular dos prédios em chamas. Muitas destas imagens mostradas no filme foram consideradas pelos norte-americanos como ultrajantes, gerando polêmica quando publicadas/exibidas e mesmo censuradas por alguns meios de comunicação. 


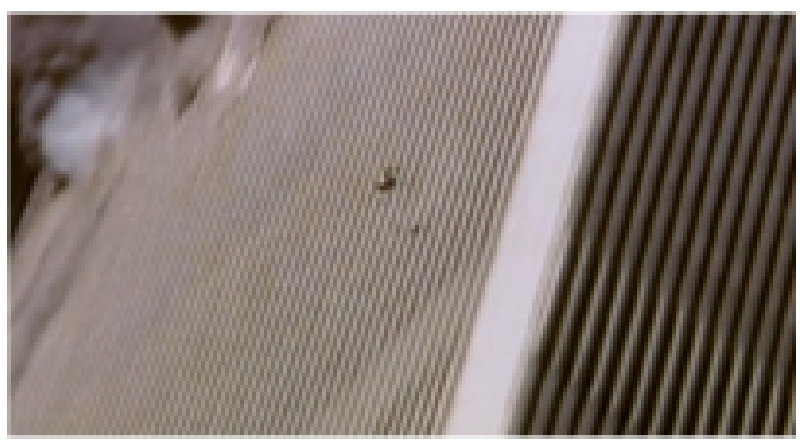

Figura 1.

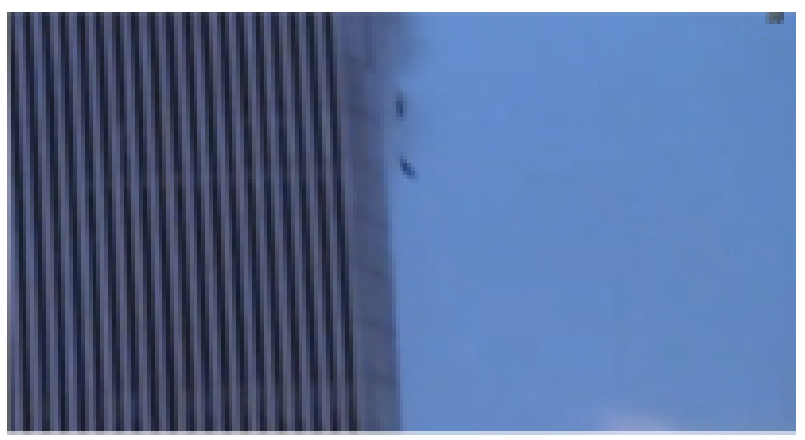

Figura 2.

O horror e a compaixão já vinham sendo construídos, mas a convocação da piedade, especificamente, se acentua bastante a partir no "crash" e atinge o ponto culminante no momento em que começamos a ouvir bips de secretárias eletrônicas e mensagens gravadas por passageiros do avião e por pessoas que estavam nos escritórios das torres para seus familiares. O filme quer que ouçamos as palavras e as entonações claramente. Não importa somente o que é dito mas, principalmente, o modo como é dito, o fluxo de emoções que aquelas vozes transmitem. Neste momento, o tecido heterofônico sai e dá lugar a uma textura bem mais rarefeita. Além das vozes, somente o som dos trinados nos "guizos", em pano-de-fundo, para que ouçamos com máxima clareza, bem perto de nós, todo o conteúdo emocional da voz da mulher que deixa um recado na secretária eletrônica dizendo ao companheiro: "Amo você, diga às crianças que também as amo, tchau amor", concluindo este segmento da narrativa em um fortíssimo de compaixão. 
Um ruído rumoroso grave invade a trilha sonora em crescendo, dando início à próxima seção. Voltam as vozes em broadcasting, agora descrevendo o momento em que a primeira torre desaba. Na trama sonora, é construída nova atmosfera cacofônica densa, com acréscimo de um sinal eletrônico, agudo e insistente aos movimentos dos ruídos graves rumorosos do desabamento, às vozes, aos impactos e aos obstinados guizos. Nada agora se aproxima do que tradicionalmente conhecemos como "musical", como era o caso do drone de notas sustentadas. Em dinâmica e densidade crescentes, essa é a "cama" sobre a qual ouvimos, também em broadcasting, vozes de ódio que clamam por vingança. "Quero que ataquemos as mães deles, quero que ataquemos os filhos deles"é a última dessas frases, que também fica repetida em loop por um tempo, em contraponto com outra voz masculina que repete uma frase em árabe, saindo a seguir para nos deixar somente com a tela preta e uma massa de ruídos espessa, áspera, incômoda, que ocupa praticamente todas as faixas de frequência e não para de crescer em volume, densidade e tessitura durante cerca de 30 segundos, fazendo os nossos ouvidos cada vez mais "arranhados" e saturados clamarem por alívio, que é justamente o que o filme nos dá a seguir, com a dádiva de um silêncio absoluto.

Nada. Tela preta e falantes silenciosos por cerca de 5 segundos. Respira o filme, respiramos nós, aliviados, mas por pouco tempo. As imagens das torres desabando, que aparecem a seguir sobre um fundo de silêncio absoluto, marcam o ponto final do discurso baseado em material de arquivo, em uma chave trágica que extrai do efeito de contraste com o tecido caótico que vinha sendo oferecido à escuta um impacto dramático importante e constrói, no silêncio, um espaço para reflexão sobre o que foi audiovisto anteriormente.

Após o momento em que a narrativa enfim entrega aquilo que passa todo o tempo prometendo - a imagem da queda das torres -, voltamos a olhar para a tela preta e, em um longo crossfade para uma tela totalmente branca, a ouvir as mesmas vozes que oram no início do filme, demonstrando uma instância autoral preocupada em "costurar" o fim com o princípio, ou seja, atenta ao equilíbrio formal da narrativa. Desta vez, contudo, vai entrando no campo sonoro a música composta por Gustavo Santaolalla e Osvaldo Golizov. Tonal, melódica, de natureza romântica e executada em cordas, o volume da música aumenta lentamente e a melodia passa a reinar absoluta na trilha sonora. No mesmo passo, a tela vai se tornando cada vez mais clara. Essas mudanças súbitas no ritmo da narrativa e na natureza do que nos é oferecido à visão e à escuta, que operam como uma espécie de "alívio lírico" em relação ao altíssimo grau de tensão do segmento anterior, preparam o desfecho da obra. Nos últimos segundos, na tela já completamente branca, surge em fade in o 
letreiro "Does God's light guide us or blind us?", ${ }^{4}$ com uma tradução em árabe da frase. O último signo do último sintagma do filme é um ponto de interrogação.

Este curto ato conclusivo do filme, decerto mereceria um investimento analítico mais vigoroso. Tomamos aqui a decisão hermenêutica de que o filme não engendra em si um programa cognitivo destinado a defender um ou outro lado do conflito no qual o ataque suicida às Torres Gêmeas está inserido. É claro que o que ouvimos com mais fartura são as vozes de testemunhas e vítimas indiretas de um ato de extrema violência. Tendemos, assim, a uma posição empática em relação aos que foram atacados. A frase final escrita na tela, nos idiomas dos dois povos envolvidos diretamente no conflito, no entanto, convoca a cognição do espectador para refletir não somente sobre esse episódio específico, mas para o hiperbólico grau de violência cometida pelo homem contra o homem, ao longo da nossa história, tendo como justificativa aparente a palavra de deuses e profetas. Na interpretação desta análise, os protagonistas dessa história não são George W. Bush e Osama bin Laden, mas sim as vozes anônimas de um povo que é representado orando e realizando ataques suicidas, enquanto um outro nos é mostrado em uma chave de pavor, desespero e ódio.

Ainda em relação à seção conclusiva do filme, mereceria também maior atenção analítica o caráter acentuadamente sentimental que a música de Santaolalla e Golizov acrescenta à experiência de apreciação, sugerindo até mesmo uma leitura retroativa do filme sob uma perspectiva (demasiadamente?) melodramática. Temendo, contudo, enveredar por reflexões que nos desviassem por demais do nosso objeto, optamos por colocar a ênfase da análise nos conteúdos gerados pelo material de arquivo, recurso do qual a seção final da obra se descarta por completo.

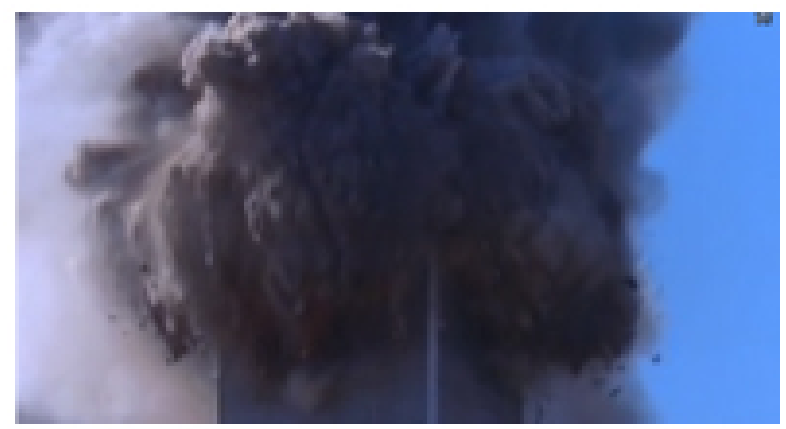

Figura 3.

4. “A luz de Deus nos guia ou nos cega?” (tradução nossa) 


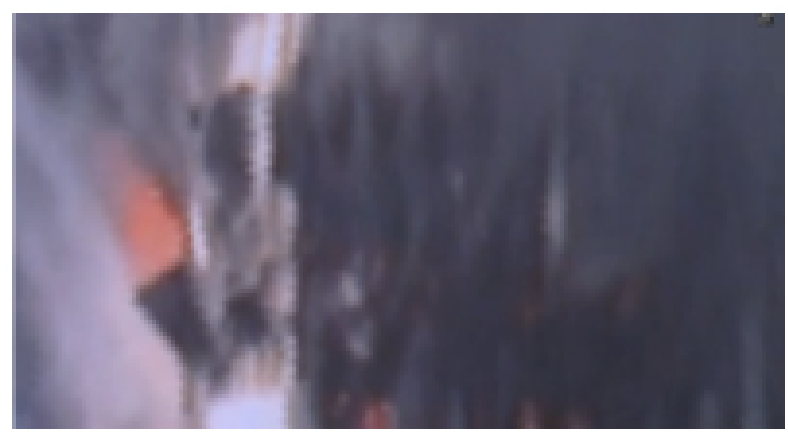

Figura 4.

\section{Considerações finais}

A título de síntese, defendemos nesta análise que Mexico é um filme que busca engajar o espectador do ponto de vista emocional, cognitivo e sensorial sobretudo a partir de estratégias que constroem, primeiro, uma posição de testemunha e um modo de produção de sentido documentarizante. O que significa que pressupomos a realidade dos registros e de seus autores, a partir do uso do recurso das imagens e dos sons de arquivo. E que, segundo, este modo de leitura é importante não apenas no sentido de construir esta posição testemunhal, mas também de intensificar as estratégias de produção de empatia e sentimento com relação aos personagens da narrativa, aos envolvidos nos atentados.

Nota-se também a presença de estratégias voltadas para a produção de desorientação de ordem cognitiva e sensorial. Embora o conteúdo da narrativa ${ }^{5}$ não seja de grande complexidade, até por fazer parte da enciclopédia de qualquer espectador médio, as informações não são dadas facilmente. É como se o filme quisesse inserir o espectador no centro do caos que se instalou naquele lugar. Como se quisesse reproduzir na apreciação todo o choque e perplexidade, toda a dificuldade em compreender e em reagir, em atribuir um sentido e um motivo ao que estava ocorrendo, produzidos pelos atentados do ponto de vista de quem os testemunhou. E, para isso, trata de desorientá-lo, fornecendo informações fragmentadas e incompletas, provocando sentimentos de angústia, ansiedade e incerteza sobre o que acontece e o que acontecerá - os mesmos que devem ter acometido aqueles que lá estavam. A tela preta, os planos rápidos e rarefeitos, não são apenas meios para produzir estranhamento por se distanciarem das convenções cinematográficas. São antes escolhas fundamentais para intensificar a desorientação, tanto cognitiva como sensorial. Cognitiva

5. Aquilo que Bordwell (1985) chamaria de fábula, no caso de obras ficcionais. 
porque a narrativa não se esforça em fornecer pistas que permitam ao espectador criar hipóteses sobre o seu desenrolar, sobre o que virá no próximo plano ou na próxima sequência - que aqui são mais sonoras do que imagéticas, importa insistir. E sensorial porque a escassez de imagens obriga o apreciador a construir sua referência espacial com base naquilo que escuta, e não no que vê.

Ainda nesta mesma chave, percebe-se também estratégias destinadas a fazer com que o espectador se sinta tragado por um turbilhão de informações incompletas que não dão conta de explicar com clareza o que estava ocorrendo. São diferentes vozes, em diversos idiomas, que se chocam, são montadas umas sobre as outras, sem que o off anterior tenha terminado - de modo semelhante ao que acontece nos primeiros minutos de filme, na montagem sonora das rezas islâmicas. Incapaz de apreender o conteúdo do que é dito, o espectador entra em um estado de anestesia cognitiva. Literalmente, desistimos de tentar entender, e o que nos resta pode ser o prazer sensorial da escuta. Ou a angústia derivada da ausência de sentido. ${ }^{6}$

Cremos, ainda, que análise tenha dado conta de explicitar a presença de uma instância autoral que organiza os materiais sonoros de arquivo em um design de acentuado rigor formal e, ao mesmo tempo, a serviço de uma progressão narrativa e dramática rica e astutamente urdida para produzir os efeitos trágicos do horror e da piedade. Nesse sentido, é notável o modo como o filme organiza informações orais factuais em um fluxo de texturas, tessituras e contrastes, construindo um espectro dinâmico que vai do silêncio absoluto ao limite de tolerância da nossa escuta a ruídos em altíssimo volume.

Embora acreditemos que a abordagem imanente, centrada no programa poético do filme e nos seus modos de engajar o espectador tenha sido uma escolha metodológica adequada para demonstrar como a obra constrói o lugar do apreciador, sabemos, é claro, que não é a única perspectiva possível. Certamente, para uma pesquisa interessada em discutir as fronteiras entre ficção e documentário, trata-se de um objeto privilegiado. Muito nos faz crer ser promissora, também, uma análise desta obra na relação com seu contexto produtivo, seu autor e seu projeto artístico. ${ }^{7}$ Iñarritú é sabidamente um diretor reconhecido por seu estilo de construir narrativas nas quais seus personagens sofrem com as determinações do acaso, tal e qual aqueles que eventualmente estavam no World Trade Center no 11/09.

6. Esta interpretação está condicionada ao fato de que o espectador/analista não é um poliglota. Mas é igualmente verdade que o filme não parece construir um espectador-modelo desta forma. Ademais, não é dificil concordar que, independente da forma como são apresentados, estes são fatos difíceis de serem compreendidos.

7. Em 2002, o diretor já tinha produzido e sido premiado com Amores Brutos (Mexico, 2000). Depois, faria 21 Gramas (Estados Unidos, 2003), Babel (França/Estados Unidos/Mexico, 2006), Biutiful (Mexico/Espanha, 2010) e Birdman (Estados Unidos, 2014). 
Aliás, interessante notar essa presença da instância autoral em um comentário irônico que ocorre nos primeiros minutos de filme, pouco antes de sermos apresentados às primeiras evidências do horror. Falamos aqui da já mencionada transmissão radiofônica que repete, em loop, a voz de um locutor que diz ser aquele "um esplêndido dia de setembro". É como se, no esforço de representar o abominável, Iñárritu quisesse dar à sua narrativa uma forma tão absurda e desnorteante quanto o é o seu próprio conteúdo.

\section{Referências bibliográficas}

Aristóteles (2006). Arte Poética. Tradução: Pietro Nassetti. São Paulo: Martin Claret.

Bordwell, D. (1985). Narration in the Fiction Film. Madison: University of Wisconsin Press.

Chion, M. (2011). A Audiovisão: som e imagem no cinema. Lisboa: Texto \& Grafia.

Didi-Huberman, G. (2012). Imagens apesar de tudo. Lisboa: KKYM Imago.

Eco, U. (1994). Seis passeios pelos bosques da ficção. São Paulo: Companhia das Letras. Tradução de: Six Walks in the Fictional Woods (Cambridge, MA: Harvard University, 1994).

Gomes, W.S. (1996). Estratégias de produção de encanto: o alcance contemporSilvada Poce contemporSilva Fia P. Textos de Cultura e Comunicaona, (35): 99-124 .

Gomes, W.S. (2004). La poética del cine e la cuestión del método en el análisis fílmico. Significação: Revista de Cultura Audiovisual, 31(21): 85-105. São Paulo: Annablue.

Gomes, W.S. (2004). Princípios de Poética (com ênfase na Poética do Cinema). In M. Pereira, R. Gomes \& V. Figueiredo (Org.), Comunica (pp. 93-125).

Odin, R. (2004). A questão do público: uma abordagem semiopragmática. In F.P. Ramos (Org.), Teoria Contemporânea do Cinema: documentário e narratividade ficcional (pp. 27-45). São Paulo: Senac.

Odin, R. (2012). Filme documentário, leitura documentarizante. Significação: Revista de Cultura Audiovisual, 39(37): 10-30. São Paulo: Programa de Pós-Graduação em Meios e Processos Audiovisuais / ECA/USP.

Odin, R. (2011). Les espaces de communication: introduction à la sémiopragmatique. Grenoble: Press universitaires de Grenoble. 


\section{Filmografia}

Mexico, 11'09”01 September 11 (2002), de Alejandro González Iñárritu. (Produção: Alain Brigand. Paris: Bac Films, 2002. DVD (134 min.), son. color.) 